\title{
Relasitas Lakuan Wayang dengan Iringan Gamelan Gagrag Yogyakarta
}

\section{Kasidi Hadiprayitno ${ }^{1}$}

Program Studi Pedalangan, Fakultas Seni Pertunjukan, Institut Seni Indonesia Yogyakarta

\begin{abstract}
The Relativity of the Wayang Play with the Gamelan Gagrag of Yogyakarta. The purpose of this is to conduct a study of the behaviour of Yogyakarta puppet style movements with puppet accompaniment music. Data obtained from observations and surveys of wayang performances held at Sasana Hinggil Dwi Abad Yogyakarta. Approach to the problem with the descriptiveanalytical method, while for discussion using aesthetic analysis, especially puppet aesthetics. Based on the analysis carried out, it is known that the wayang movements with accompaniment form a harmonic structure. Puppet accompaniment gending includes gending ageng, ladrangan, ketawang, lancaran, playon and sampak. At the same time, in terms of aesthetics, it takes care of unity or integrity, strength, and complexity (unity, intensity, and complexity).

Keywords: wayang performance; movement and music; harmonic structure
\end{abstract}

\section{Pendahuluan}

Pergelaran wayang kulit purwa yang ada sekarang ini dikenal oleh masyarakat Jawa, utamanya kawasan Yogyakarta, sejak lama paling tidak abad XVIII hingga mencapai puncak kejayaannya pada era pemerintahan Raja Sultan Hamengku Buwana VIII. Hal itu disampaikan dalam penelitian yang dilakukan oleh R.M. Soedarsono, walaupun pijakan penelitian itu berdasarkan perkembangan wayang wong atau wayang orang gaya Yogyakarta (1990). Tidak dapat dipungkiri bahwa wayang wong gaya Yogyakarta banyak dipengaruhi oleh wayang kulit purwa yang lebih dulu eksis di masyarakat Yogyakarta.

Istilah gagrag Ngayogyakarta sesungguhnya merupakan alomorf dari gaya Yogyakarta, di samping gaya kraton (Hadiprayitno, 2019). Masing-masing gaya memiliki ciri sendirisendiri. Gaya kraton lebih mengacu pada budaya kraton, sedangkan gagrak pedalangan sebagaimana dimaksudkan dalam penulisan ini, sesungguhnya adalah gaya di luar kraton yang sering dilakukan oleh para seniman dalang. Kraton sebagai orientasi sebab para dalang juga berperan sebagai abdi dalem kraton, sehingga tentu saja dalam berkarya banyak dipengaruhi oleh gaya kraton (Kayam, 2001: 35). Namun demikian, kebebasan berkarya seni yang melekat kepada diri para dalang menyebabkan gaya pedalangan lebih mendominasi pergerakan seni pedalangan, khususnya di Yogyakarta. Berkenaan dengan hal itulah maka menarik untuk dilakukan pengkajian terhadap gagrag pedalangan, yang meliputi konsep relasitas estetik antara pergelaran wayang dan gending-gending iringan wayang. Konsep estetik sesungguhnya menjadi pijakan dalam berkarya seni pedalangan, walaupun barangkali belum secara sadar dipahami oleh praktisi seni pedalangan. Oleh sebab itulah penulisan ini menjadi kancah studi berkaitan dengan konsep keindahan dalam seni pedalangan, khususnya gagrag pedalangan. Berdasarkan pemikiran

1 Alamatkorespondensi: Program Studi Pedalangan, Fakultas Seni Pertunjukan, ISI Yogyakarta, Jln. Parangtritis km.6,5 Sewon, Bantul, Daerah Istimewa Yogyakarta. Email: kasidihp15@gmail.com. 
yang telah disampaikan tadi, kiranya perlu diupayakan secara terus-menerus studi seperti ini guna pengembangan teori dalam ilmu pedalangan yang sangat dibutuhkan di masa-masa kini dan yang akan datang. Masalah penulisan secara lebih rinci dapat dirumuskan sebagai berikut.

a. Dasar-dasar estetik apakah dalam pergerakan wayang dengan gending iringan wayang?

b. Ada berapa macam gerak-gerak wayang dalam pertunjukan wayang itu?

c. Gending-gending apa saja yang digunakan dalam mengiringi pergelaran wayang?

Dasar pemikiran dari aktivitas ini adalah berbasis pada penelitian yang hasilnya dapat ditindaklanjuti dengan program model pembelajaran pedalangan atau pewayangan gaya Yogyakarta. Secara sederhana, model pembelajaran ini akan dapat diterapkan serta mudah dikerjakan oleh berbagai pihak yang berkepentingan. Seperti diketahui bahwa kegiatan penelitian mementingkan proses berpikir yang sistematis dan konstruktif, sehingga dapat dimanfaatkan demi pengembangan ilmu pengetahuan, teknologi, dan seni. Sasaran utamanya adalah mampu memberikan kontribusi terhadap peningkatan kesejahteraan masyarakat, terutama masyarakat pedalangan yang selama ini belum memadai. Ada tiga tahap program penulisan ini, (1) adalah dilakukan secara literer dan pengamatan terhadap pergelaran wayang yang selanjutnya dipergunakan sebagai sumber data gending-gending iringan pakeliran, seperti di Sasana Hinggil Dwi Abad yang dilakukan secara random; (2) hasil penulisan literer sebagai data itu akan dipakai sebagai dasar analisis relasitas gending iringan wayang dengan aktivitas pergelaran wayang oleh dalang; (3) hasil analisis berupa luaran teoritis yang sederhana, mudah dipahami, dan dapat diaplikasikan secara praktis. Adapun metode untuk analisis adalah sebagai berikut. a. Metode objektif, yaitu suatu cara mengemukakan secara deskriptif sebagaimana adanya objek material yang akan dipergunakan sebagai sasaran penulisan, dalam hal ini adalah gerak-gerak lakuan wayang dalam pergelaran dengan iringan pakeliran gagrag pedalangan Yogyakarta. Untuk memperoleh data, dilakukan pengumpulan secara acak berbagai cerita lakon wayang, salah satunya adalah pergelaran wayang di Sasana Hinggil Dwi Abad Yogyakarta.

b. Metode analisis yang dilakukan sekaligus sebagai objek formal adalah ilmu seni pedalangan, utamanya adalah estetika pedalangan. Bermula dari analisis bentuk gerak-gerak lakuan wayang dengan gendinggending iringan wayang, dan dilanjutkan dengan analisis antara relasitas gending dengan gerak-gerak wayang meliputi adegan, suasana adegan, sekaligus dengan karakter tokoh wayang.

\section{Pembahasan}

Bagian ini berusaha untuk memaparkan penjelasan umum dan penjabaran masalah yang berkaitan dengan lakuan yang berupa gerak-gerak wayang yang meliputi berbagai pemunculan tokoh wayang dalam pementasan. Berdasarkan pengamatan di lapangan, diketahui bahwa dalam era kekinian telah terjadi perubahan dan pergeseran kebutuhan pergelaran lakon wayang kulit purwa gaya Yogyakarta dengan gending-gending iringan. Selanjutnya, dibahas juga mengenai konsep estetik, khususnya yang berkaitan dengan ranah seni. Setelah dilakukan tinjauan atau paparan umum berbagai hal yang terkait dengan konsep estetik karya seni, barulah pembahasan dilakukan pada relasi estetik pergerakan lakuan wayang dengan iringan wayang. Demikian juga halnya keterkaitan jenis gending-gending iringan pergelaran wayang dengan pergerakan lakuan adegan cerita lakon wayang. Faktor-faktor apakah yang menyebabkan lahirnya bentuk iringan yang merupakan salah satu bentuk karya seni itu; apakah yang dimaksudkan dengan karya seni ditinjau dari segi hasilnya atau 
wujud yang kasat mata (Dewey, 1934: 2530), menerangkan bahwa unsur manusiawi memegang peranan penting dalam proses pemunculannya. Karya seni adalah hasil pengungkapan nilai dan pengungkapan perasaan seniman yang bersangkutan. Berkaitan dengan seniman, berarti pengaruhpengaruh di luar wujud fisiknya dan dari dalam diri seniman itu sangat dominan tergambar di dalamnya.

Gending iringan wayang selalu dimunculkan pada setiap adegan mulai dari jejer pertama sampai dengan bagian akhir pertunjukan yang ditandai dengan tancep kayon. Para dalang yang ketika mempergelarkan sebuah lakon berdasarkan pengamatan dan data yang diperoleh, ternyata memiliki persamaan dan perbedaan. Hal ini tergantung pengetahuan dan kemampuan individu atau kelompok pendukung sebuah pergelaran, misalnya keberadaan pengrawit, swarawati, dan penyangga pergelaran lainnya. Banyaknya pertunjukan wayang kulit purwa gaya Yogyakarta merupakan kekayaan sebagai sumber pengetahuan yang menarik dilakukan studi secara komprehensif. Namun, keterbatasan waktu dan ruang kajian menjadi pertimbangan untuk membatasi materi. Tentu saja dipilih data yang dapat mewakili secara keseluruhan, sehingga relasitas pergerakan wayang dengan gending-gending iringan wayang dilakukan secara random atau acak yang berhasil ditemukan di lapangan, kemudian ditambah pula data dari pergelaran rutin di Sasana Hinggil Dwi Abad Yogyakarta. Dalang-dalang yang berkesempatan menggelar pertunjukannya di Sasana Hinggil Dwi Abad dipandang dapat mewakili keberadaan tren pada zamannya, termasuk gaya individual dan bentuk seni pedalangannya karena sebagian besar dalang yang ditampilkan telah memiliki reputasi serta memperoleh pengakuan dari masyarakat penonton di kawasan Yogyakarta, sehingga tidak meragukan lagi dari segi kualitas dan kepiawaian dalam hal mendalang.

Situasi era milenium seperti sekarang ini rasanya orang tidak mudah untuk memperoleh kesenangan dan manfaat dari karya-karya seni modern. Akan tetapi, hal itu tidak berarti bahwa karya-karya seni bukan lagi untuk manusia pada umumnya, namun kemajuan kebudayaan manusia telah membuat salah satu penyebabnya, antara lain kesenian menjadi lebih satisfikatif daripada hasil kesenian untuk keperluan sehari-hari. Hal ini sejajar dengan kemajuan ilmu pengetahuan dan seni serta susunan masyarakatnya sehingga diperlukan pengalaman, pengetahuan, dan latihan khusus dalam mengambil manfaat kesenian tersebut. Misalnya, pengenalan kembali kepada akar kebudayaan sendiri serta lewat program apresiasi seni. Keberadaan karya seni tidak dapat terlepas dari unsur keindahan sehingga perlu kiranya memahami lebih mendalam hal ikhwal pengertian keindahan, terutama yang juga disebut sebagai dasar estetik karya seni.

Sesuatu hal dikatakan indah secara alamiah kalau hal itu membiarkan gagasan yang ada di dalam dirinya tampil dengan cemerlang. Sesuatu dikatakan indah secara artistik bukan hanya pengulangan atau tindasan atau copy hal-hal yang terdapat dalam alam. Sebaliknya, tugas seni adalah membiarkan ide-ide tampil dengan kedalaman dan kekuatan yang sama sekali baru dan merefleksikan rahasiarahasia terdalam dari realitas kehidupan sehari-hari dalam karya-karya kreatif seni. Karena alasan inilah maka maksud dan tujuan pokok seni adalah menyajikan dan menggambarkan gagasan-gagasan sehingga seni bukan semata-mata menghasilkan benda-benda atau barang-barang, melainkan harus juga menimbulkan kesenangan. Satu hal penting adalah kemampuan karya seni yang mampu mengomunikasikan berbagai informasi kehidupan kepada penikmat atau audience. Karya seni adalah sarana untuk mengekspresikan semua gagasan seni kepada khalayak. Itulah sesungguhya esensi dari penikmatan estetik.

Setiap karya seni merupakan kebulatan yang tersusun dari bagian-bagian secara tertib. Bagian-bagian itu mendukung atau membangun suatu tujuan yang menyeluruh. 
Tidak satu pun bagian yang merupakan sebuah pecahan, penggalan, atau fragmen yang berdiri sendiri. Setiap bagian memiliki andil yang penting bagi terciptanya sebuah keseluruhan karya yang bulat dan utuh. Inilah yang kemudian disebut sebagai kesatuan organis (Gie, 2004: 76). Oleh sebab itulah disampaikan pendapat ahli estetika, Monroe Beardsley yang menyatakan bahwa sesuatu yang indah atau karya estetik mengandung tiga unsur penting, yaitu (1) unity 'kesatuan', yang dimaksudkan adalah bahwa suatu karya seni tersusun dengan sedemikian baik berdasarkan kaidah-kaidah seni yang bersangkutan serta memiliki bentuk yang sempurna. Secara struktural jalinan antarunsur pembentuknya memiliki kaitan masing-masing sesuai dengan fungsi dalam rangka membentuk kesatuan. (2) Complexity 'kerumitan', berbagai unsur struktur yang membangun sebuah karya seni memiliki keragaman sebagai daya tarik serta kekhasan dari karya yang bersangkutan. (3) Intensity 'kesungguhan' artinya bahwa suatu karya estetis yang baik pastilah memiliki kualitas tersendiri sehingga menjadi pembeda dengan karya lain (Gie, 2004: 43). Seni itu pada dasarnya bersifat abadi. Artinya, selalu ada dari waktu ke waktu, dan berkembang sesuai dengan tuntutan perubahan zaman yang tengah berlangsung. Pergelaran wayang secara menyeluruh dapat digolongkan ke dalam seni yang menekankan pada aspek etika dan moralitas manusia, dan tergolong ke dalam kelompok yang mengandung nilainilai estetik sehingga dalam jagad pewayangan telah terbukti sejak beberapa abad yang lalu adanya nilai-nilai moral yang penting dalam kehidupan orang Jawa. Bahkan lebih dari itu, keseluruhan pertunjukan wayang itu sesungguhnya merupakan seni tradisional yang paling lengkap karena memiliki kandungan berbagai cabang seni.

Dimensi etika dan estetika dalam jagad pakeliran wayang kulit purwa gaya Yogyakarta sesungguhnya bertumpu kepada perilaku kultural yang dikenal dalam suatu masyarakat tertentu, dengan asumsi bahwa suatu kebu- dayaan tertentu memiliki kadar keberbedaan dengan budaya yang lain, dan tidak ada klaim bahwa yang satu lebih baik daripada yang lainnya. Adat istiadat dari berbagai masyarakat yang berbeda adalah suatu kenyataan yang ditemukan dalam kehidupan masyarakat. Tidak ada benar dan salah karena hal itu mengimplikasikan adanya standardisasi kebenaran dan kesalahan, padahal segalanya akan sangat bergantung pada masyarakat pendukung budaya yang bersangkutan, sehingga pandangan terhadap budaya lain pun akan dipertimbangkan dengan budaya yang berlangung di lingkungan masyarakatnya. Jalan yang benar adalah jalan yang ditempuh oleh para pendahulu dan yang telah diturunkan secara turun-temurun, sehingga tradisi itu menjadi pembenaran dirinya sendiri. Istilah tapa brata yang muncul dalam banyak cerita lakon wayang, sesungguhnya mengacu pada budaya Jawa yang masih dijalankan oleh sebagian masyarakat Jawa, sehingga keberadaan lakon wayang itu pun dilakukan dalam rangka ngleluri atau nguri-uri 'menjalankan hal-hal yang baik' dalam budaya Jawa. Tapa brata adalah konsep ulah batin dalam budaya Jawa. Tapa berasal dari bahasa Sanskerta tapas 'memanaskan' yang artinya adalah cara untuk mengendalikan hawa nafsu angkara murka yang senantiasa ada di dalam diri manusia. Hal ini dilakukan dengan cara pranayama 'napas', yakni mengatur keluar-masuknya napas dengan tujuan untuk menggerakkan daya hidup manusia. Adapun brata 'laku' yang dimaksudkan adalah mengurangi makan, minum, dan tidur. Tujuannya untuk mengelola keinginankeinginan negatif agar tidak mengganggu kesempurnaan gaib yang ingin dicapai dalam samadi. Ketika manusia gagal melakukan tapa brata, artinya gagal dalam mencapai kesempurnaan samadi maka niscaya akan jatuh ke jurang kesengsaraan. Hal ini sebagaimana dilakukan oleh Batara Guru ketika sedang melanglang jagad bersama istrinya, dan justru mendapat nestapa, sehingga punya anak yang berparas yaksa yang dikonotasikan sebagai manusia buruk rupa dan jahat, yaitu Batara 
Kala. Gambaran seperti itulah sebagai contoh perbuatan yang kurang terpuji, niscaya akan memperolah ketidakbaikan pula, walaupun seseorang tersebut memiliki kedudukan dan kekuasaan yang tinggi.

\section{Konsep Estetik dalam Wayang}

Sebagai gambaran kaitan keberadaan pergelaran wayang yang menyiratkan kebenaran estetik dengan pemikiran structural, dapat disimak pendapat Gadamer, bahwa di dalam seni mengandung nilai kebenaran (Palmer, 2005: 192). Tentu saja kebenaran itu diakui secara umum sebab memiliki kelogikaan walaupun tidak melalui penalaran, dan sebaliknya berlawanan dengan penalaran. Dalang sebagai pelaku memiliki kedudukan penting dalam pertunjukan wayang sekaligus fungsi yang sangat sentral, baik sebagai pembawa cerita lakon pergelaran wayang, juga sebagai pimpinan pergelaran. Sebagai contoh dalam pembawaan cerita lakon wayang kulit purwa tertentu, bahwa setiap pembawaan suluk wayang yang menyangkut ilustrasi adegan maupun karakter wayang tertentu yang berwujud nyanyian solo yang dilakukan oleh dalang, yaitu pada pembawaan jenis sulukan tertentu ketika jatuhnya nada akhir adalah nada 6, sementara gong yang dibunyikan adalah nada 2, dan itu dilakukan selalu seperti itu, sehingga efek bunyi yang dihasilkan disebut bunyi gembyung. Satu lagi contoh adalah bunyi gong besar selalu berbunyi pada setengah atau bahkan satu hitungan lebih akhir dari jatuhnya suara nada sulukan wayang atau ricikan instrumen gending gamelan. Efek ini menimbulkan rasa lega dalam hati pendengarnya, demikian halnya pengulangan-pengulangan suara ong, heng, dan hong dalam sulukan wayang memberikan kesan estetis pada penikmatnya. Pandangan ini dapat dijumpai dalam budaya Jawa, yaitu bahwa aspek estetis sesungguhnya terjelma ke dalam perilaku keseharian orang Jawa, misalnya sikap permisif, menghindari konflik, menghormati orang yang lebih tua, dan seterusnya. Oleh sebab itu, ketika berkarya seni pun selalu menunjukkan nilai estetis berdasarkan kandungan seni masingmasing cabang jenis seni yang dihasilkanya.

Keindahan pada karya seni bersumber pada pemahaman budi manusia terhadap pola alam semesta. Seniman menangkap hubungan-hubungan dalam alam dengan emosinya dan kemudian mengungkapkan kembali dalam bentuk yang diperjelas atau diobjetivisikan. Keindahan merupakan suatu hasil cinta manusia terhadap pola yang berdasarkan pemahamannya pada pola alam. Hal ini penting ukuran karya seni, bendanya sendiri, dan segi subjektif dari pengalaman yang timbul pada si pengamat. Seni sebagai a logic of aesthetics form, seni sebagai bentuk estetik yang logis, sehingga seni itu mampu memberikan rasa puas bagi penikmatnya disebabkan oleh beberapa hal sebagai berikut.

1. Mengungkapkan keserasian antara bentuk dan isi.

2. Menarik menurut perasaan, perenungan terhadap karya seni dengan diliputi rasa puas.

3. Karya seni menunjukkan kekaryaan tentang hal-hal penting yang menyangkut manusia dan memperbesar kehidupan perasaan.

4. Karya seni membawa manusia masuk ke dalam suatu dunia yang dicita-citakanmembebaskan manusia dari ketegangan atau suasana sehari-hari.

5. Karya seni menyajikan kebulatan yang utuh yang mendorong pikiran pada perpaduan mental manusia.

Berdasarkan pemaparan di atas dapat dikatakan bahwa relasitas lakuan gerak wayang dengan gending iringan pakeliran pun merupakan kesatuan yang seimbang dan harmonis dari paling tidak tujuh unsur penting yang terkandung di dalam dimensi seni pewayangan, yaitu seni drama, seni lukis, seni kriya, seni sastra, seni suara, seni musik iringan, dan seni gaya (Haryanto, 1988: 2-9).

Susunan kisah lakon wayang dalam format pergelarannya sejak dari awal sampai akhir, secara utuh mengandung unsur-unsur 
sebagaimana dipaparkan di atas. Penuangan atau pengejawantahan berbagai unsur pembentuk cerita lakon berdasarkan konvensi seni pewayangan, terutama adalah gaya Yogyakarta. Tuntutan estetik secara teoretik telah terpenuhi dan dirangkai sedemikian rupa, sehingga kaidah-kaidah estetik konvensi gaya yogyakarta secara terpadu dan utuh dapat diketahui dengan jelas.

\section{Estetika Gending-gending Iringan Wayang}

Pertunjukan seni tradisional wayang kulit purwa merupakan jenis kesenian yang telah melampui perjalanan yang sangat panjang. Setidaknya sejak abad IX, sampai dengan saat era millenium masih terjaga keberadaannya di Jawa, khususnya, dan Indonesia pada umumnya. Oleh sebab itu, UNESCO berkenan memberikan penghargaan khusus wayang sebagai warisan budaya Indonesia tak benda (Solichin, dkk., 2012). Ada beberapa gaya pewayangan yang ditemukan di Indonesia, yang terkenal berdasarkan wilayah budayanya, yaitu gaya Yogyakarta, Surakarta, Banyumasan, Cirebon, Malangan, Bali, Madura, Lombok, Banjar, dan sebagainya. Pewayangan gaya Yogyakarta dan Surakarta berkembang cukup luar biasa sehingga menjadi lebih popular di antara gaya yang lainnya. Hal itu dipengaruhi oleh campur tangan dan peranan Kraton Yogyakarta dan Surakarta sebagai pusat kebudyaan Jawa terus mengupayakan eksistensi budaya wayang tersebut, termasuk jenis dan macam budaya dan seni yang lain. Gaya itu muncul setelah terjadinya Perjanjian Giyanti tahun 1755, yakni suatu kesepakatan pembagian wilayah dan kekuasaan pemerintahan berikut wilayah budayanya, yakni Mataram menjadi Surakarta dan Yogyakarta (Gustami, 2000: 95). Secara konsep dan teknis, seni dan budaya gaya Surakarta memiliki corak tersendiri yang dapat dibedakan dengan gaya-gaya lainnya, seperti Yogyakarta atau Mataraman. Begitu pula dalam hal seni karawitan, iringan pakeliran gaya Yogyakarta memiliki cirinya sendiri. Berdasarakan konsepnya, suatu karya seni mengikuti kebiasaan serta kebebasan yang dituangkan lewat berbagai cara sekaligus sebagai pembeda dengan bentuk karya seni yang lainnya. Lebih jauh dalam perkembangannya diikuti oleh kelompok budaya tertentu dari zaman ke zaman secara turun-temurun, generasi ke generasi, selanjutnya menjadi sebuah kebenaran. Konsep dasar itulah yang kemudian mendapat predikat sebagai nilai edipeni dan adiluhung.

Konsep estetik iringan pakeliran yang dimaksudkan sesungguhnya adalah relasi harmonisasi unsur-unsur bunyi musik gamelan sebagai aransemen iringan pertunjukan cerita lakon wayang. Esensinya berwujud relasi antara bentuk dan isi. Bentuk menyangkut tentang fisik gending-gending iringan wayang, misalnya bentuk lancaran, ladrang, ketawang, gending, ayak-ayakan, playon, sampak, dan sebagainya. Adapun isi adalah jenis-jenis sistem garap gending tertentu yang menyangkut persoalan teknis, misalnya gending-gending iringan wayang gaya Yogyakarta yang telah dibakukan dalam buku pengajaran Habirandha Karaton yang ditulis oleh Mudjanattistomo, dkk. (1977). Masalah ini kiranya perlu diberikan penjelasan secara komprehensif untuk mendapatkan gambaran tentang relasi estetik antara bentuk dan isi gending iringan pakeliran wayang, terutama yang berhubungan dengan data empirik yang terjangkau dalam penelitian ini.

Pemikiran estetika gamelan secara umum pernah disampaikan oleh tokoh pendidikan yang sangat berwibawa, yaitu Ki Hadjardewantara. Beliau mengatakan bahwa salah satu model pembelajaran yang mengedepankan kepekaan rasa adalah lewat seni tradisi gending gamelan. Pelajaran gending tidak hanya diperlukan sebagai sarana pengetahuan intuitif dan keterampilan memainkan gending gamelan belaka namun ternyata juga penting untuk membangkitkan hidup kebatinan. Sebab, gending gamelan mampu menuntun pikiran manusia ke arah 
rasa keindahan yang berirama rhythmisch gevoel dan menghidupkan rasa keindahan aesthetisch gevoel serta mengheningkan rasa kesusilaan ethisch gevoel (Sumarsam, 2003: 168-169). Relasi antara gending-gending gamelan dan konsep etika serta estetika Jawa berdasarkan ungkapan Ki Hadjardewantara, merupakan salah satu pengejawantahan kehidupan keseharian masyarakat Jawa yang dapat diketahui lewat sikap, perilaku, dan cara berinteraksi antarmasyarakat. Misalnya, dalam etika memainkan instrumen ricikan gamelan, seluruh pemainnya duduk bersila dan tidak seorang pun bermain sambil berdiri. Duduk bersila dalam pandangan orang Jawa adalah sikap duduk menghormat kepada orang lain yang ada di depannya. Hampir pasti orang dalam sikap ini menunjukkan penghormatan penuh, termasuk pandangan mata orang duduk bersila dengan sendirinya akan memandang ke arah bawah. Demikian pula dengan muka dan kepalanya, tentu akan ikut menunduk. Tanpa disadari, sikap seperti menunduk berlangsung mengalir demikian saja, dan menghasilkan sikap hormat yang luar biasa penuh sopan santun. Dengan demikian, menabuh gamelan pun sesungguhnya merupakan pembelajaran budi pekerti dalam rangka menjalin relasi horizontal antarmanusia yang lebih baik. Dalam berpakaian, pemain gamelan mengenakan pakaian tradisional yang disebut kejawen, berkain, baju surjan, serta mengenakan penutup kepala yang disebut udeng atau iket. Cara berpakaian seperti itu adalah sebagai pembentuk karakter si pemakainya agar selalu bergerak penuh perhitungan, tidak tergesa-gesa walaupun terkesan lamban. Namun, sesungguhnya sikap seperti itu merupakan suatu pengambilan tindakan yang penuh perhitungan agar tepat dalam memutuskan sesuatu. Perwujudannya secara anatomis, karakter pakaian kejawen akan membatasi gerak fisik fleksibilitas orang yang memakainya. Misalnya, perubahan posisi seseorang yang tengah duduk, kemudian beranjak berdiri akan melangkahkan kakinya, pastilah orang tersebut sejenak membetulkan bagian kain yang dikenakannya yang disebut wiron. Dalam melangkahkan kaki juga harus memperhatikan langkah dan posisi tangan memegangi wiron. Hal ini kelihatannya hanya masalah kecil atau sepele, tetapi mampu menunjukkan sikap orang yang bersangkutan terkesan "halus" karena sesungguhnya watak manusia tidak seluruhnya dilihat dari cara berpakaian, cara duduk, serta cara berjalannya.

Konsep estetik gending-gending iringan pakeliran atau iringan wayang sesungguhnya masih terkait dengan aspek mitos, yaitu bahwa dominasi gending tertentu dalam keperluan penyajian lakon wayang dibutuhkan untuk membawa suasana ke dalam nuansa mistis. Artinya, gending iringan wayang ditengarai memiliki spesifikasi karakter yang berkaitan dengan hal-hal mistis, seperti penghantar pembacaan doa menjelang dalang mencabut gunungan dari tengah kelir, yang biasanya dilakukan tanpa dinarasikan. Sifat yang lainnya adalah dari segi bentuk gending yang pendek, yaitu jenis ayak-ayakan. Gending yang pendek akan memudahkkan terjadinya reduplikasi atau pengulangan-pengulangan yang mengiringi adegan-adegan penting dalam penyajian satu lakon wayang yang dilakukan oleh dalang. Banyaknya pengulangan dipandang memiliki kekuatan mistis sehingga mampu mempengaruhi proses konsentrasi dalam meditasi, baik langsung oleh dalang maupun seluruh orang yang berkepentingan dalam acara tersebut (Hadiprayitno, 2017: 28-30).

Sebagai gambaran yang lebih jelas adalah pembawaan dari segi wilayah nada musik gamelannya. Misalnya, nada 1 disebut barang dan nada 5 atau lima tergolong wilayah Pathet Sanga. Dua wilayah nada inilah yang menjadi titik pengambilan susunan gendingnya yang menuntun dan melahirkan nuansa suara berat. Suara berat tepat dan lazim digunakan untuk melantunkan doa-doa dan pembacaan mantra guna permohonan kepada Tuhan. Kekuatan nada satu dan lima ternyata memiliki kekuatan dengan simbolisasi konsep keblat papat lima pancer dalam pemikiran kosmologi 
Jawa, sebagaimana disampaikan oleh Sumukti (2005). Sampai sekarang satuan lima bersifat kosmik ternyata masih merupakan hal yang penting dalam tata cara berpikir orang Jawa. Pola itu misalnya dapat dilihat dari konsep kadang papat lima pancer 'saudara empat lima pusatnya' sebagai konsep kosmik jagad cilik 'jagad kecil'. Manusia yang dilahirkan di dunia ini dari perspektif budaya Jawa, telah dibarengi dengan keempat saudaranya, yang disebut tembuni atau ari-ari, tali pusat atau pusar, dan air ketuban dianggap sebagai kakak dari bayi yang tengah lahir itu, sehingga sering disebut sebagai kakang kawah adi ari-ari 'kakak kawah adik ari-ari'. Kebiasaan orang Jawa suka menyimpan tali pusat bayi yang bersangkutan tentunya setelah dalam keadaan kering, kelak jika sekali waktu anak yang bersangkutan menderita sakit, maka tali pusat itu dapat dipergunakan sebagai obat sakit, seperti sakit panas. Sampai saat ini hal tersebut masih dipercaya bahwa setiap bayi punya empat saudara, dan dengan badannya sehingga diyakini bahwa setiap manusia Jawa setidaknya, dilahirkan di dunia dengan satuan lima. Oleh sebab itu, adegan dalam rangka Pathet Sanga dipilih untuk adeganadegan penting, yaitu nasihat spritualistik dari pendeta kepada tokoh utama dalam suatu lakon.

Keberadaan konsep estetik iringan pakeliran wayang sesungguhnya sangat mendasar sebagai komponen penting yang tidak terpisahkan hubungannya dengan pergelaran wayang. Soetarno (2007) dalam buku Estetika Pedalangan, telah memberikan penjelasan panjang lebar tentang seluk-beluk konsep iringan pakeliran wayang. Konsep yang paling penting adalah konsep persebaran dan distribusi sejumlah gending yang dipergunakan dalam iringan pakeliran wayang. Konsep-konsep itu adalah konsep mungkus 'membingkai', 'mewadahi', dan 'membatasi'; konsep nglambari 'memperkuat', 'memberi ilustrasi', dan 'menegaskan'; konsep nyawiji 'menyatu' dan luluh'. Sesungguhnya, konsep estetik yang ditawarkan ini sangat toleran, artinya dapat dikenakan pada semua gending iringan pakeliran secara umum, bahkan pada gaya pewayangan seperti pewayangan gaya Surakarta dan Yogyakarta, baik dalam kapasitas sebagai gending tradisi maupun gending garapan baru atau nontradisi. Hampir semua dalang memiliki kecenderungan yang sama dalam hal pendistribusian gending iringan pakelirannya, misalnya dalam pembawaan bentuk ayak-ayak, lancaran, ladrang, ketawang, gending, srepegan, sampak, dan lain-lain. Secara bervariatif dan berselangseling di antara gending-gending itu selalu mewarnai pergelaran wayang, sesuai dengan suasana adegan yang diinginkan oleh dalang. Jalinan antargending ini tidak semua dalang memiliki kesamaan dalam penggunaannya. Hal itu dipengaruhi oleh lakon, karakter, dan suasana yang dibangun. Kehadiran gendinggending garapan baru sebenarnya lebih kental dengan model-model atau tipe pergelaran wayang yang menyesuaikan dengan tuntutan zamannya. Hal tersebut akan menunjukkan adanya distansi antara dalang yang tergolong tua dan dalang muda, seperti era Ki Timbul Hadiprayitno dengan era dalang muda Ki Seno Nugroho dan dalang-dalang seangkatannya. Pada era tahun 2010 sampai 2020-an model pertunjukan wayang mengalami perubahan yang sangat signifikan, yaitu ditandai dengan hadirnya adegan-adegan flash back pada awal pergelaran lakon wayang. Bentuk gendinggending iringan wayang pun memberikan warna yang berbeda, yaitu dominasi iringan wayang menjadi sangat menonjol sehingga sifatnya lebih ke arah ilustratif, bahkan cenderung hanya membutuhkan aspek-aspek bunyi musik gamelan tanpa menunjuk pada jenis gending tertentu. Untuk memudahkan pemahaman terhadap penggunaan sejumlah gending iringan pakeliran wayang, konsep estetik model Soetarno dan kawan-kawan kiranya lebih tepat sehingga dapat dipakai sebagai dasar penentuan kualitas gendinggending tersebut menjadi harmoni antara wayang dan gendingnya, dan setidaknya dapat mendukung sebuah gending iringan 
wayang dibawakan dalam sebuah penyajian cerita lakon wayang. Selanjutnya, dijelaskan bahwa konsep estetik dalam gending pakeliran wayang itu mengacu kepada teknis permainan instrumen gamelan yang secara harmoni terpadu dengan kebutuhan pergelaran lakon wayang. Perlu diketahui bahwa pada dasarnya, semua jenis gending yang dipergunakan oleh dalang dalam sebuah pertunjukan lakon wayang dapat dipastikan selalu disesuaikan dengan kepentingan suasana adegan yang tengah berlangsung. Untuk lebih mengetahui distribusi sejumlah gending yang dipergunakan dalang-dalang yang dipakai sebagai pijakan analisis, maka diperlukan tinjauan secara detail dari berbagai unsur perubahan serta pergeserannya.

\section{Gending-gending Pakeliran Wayang Kulit Purwa Gaya Yogyakarta}

Pergelaran wayang secara adat tradisional sampai dengan saat masih dilakukan sesuai dengan tujuan dan fungsinya, terutama pergelaran wayang di dalam kraton. Pergelaran wayang di luar kraton juga banyak ditemukan hal yang sama, tentu saja dalam situasi yang berbeda. Biasanya berkaitan dengan acara-acara penting, seperti bersih desa, hajatan, peringatan peristiwa tertentu, dan sebagainya. Bahkan, pada sebagian teks cerita lakon di kraton berikut pergelarannya dianggap sebagai pusaka, misalnya naskah lakon wayang wong (Soedarsono, 1990). Tidak mengherankan apabila di kraton itu juga terdapat sejumlah abdi dalem yang khusus pada bidang-bidang seni tertentu, seperti pedalangan dan pewayangan, tari, karawitan, dan sebagainya sehingga pada masa-masa tertentu, seperti ulang tahun raja, berbagai bentuk seni itu diberikan kesempatan untuk menampilkan kebolehannya. Tidak ketinggalan pula adalah pergelaran wayang kulit purwa yang juga menjadi salah satu pilihan yang tampil pada acara tersebut. Lakon-lakon wayang yang dipentaskan serta gending-gending pakeliran telah tersusun dengan lengkap sampai dengan saat ini yang kemudian disebut dengan istilah pakem pakeliran wayang berikut gending-gendingnya (Nojowirongko, 1960; Mudjanattistomo, dkk., 1977).

Tampaknya, istilah pakem itu menjadi permasalahan yang menarik untuk diteliti secara khusus. Umar Kayam dalam bukunya, Kelir Tanpa Batas (2001), menjelaskan sesungguhnya pakem adalah nilai tawarmenawar konsep estetik berdasarkan era zaman yang tengah berlangsung. Oleh sebab itu, keberadaan gending-gending wayang secara kontinuitas tetap berlangsung. Sebaliknya, terjadi pula perubahan-perubahan yang juga mendapatkan tempat di kalangan khalayak dan pendukung budaya wayang. Uraian selanjutnya satu persatu adalah sebagai berikut.

\section{Kontinuitas dan Perubahan Gending- gending Wayang}

Kontinuitas memiliki pengertian pemakaian gending-gending wayang secara tradisi yang berlaku di dalam kraton dan para dalang ngagrag Yogyakarta. Sebagai gambaran adalah pakeliran yang disajikan oleh Ki Timbul Hadiprayitno dan dalang seangkatannya, dengan dalang Seno Nugroho beserta seangkatannya. Dalang kelompok sepuh atau tua memilih menggunakan gending-gending yang masih lekat dengan gending-gending kraton atau pakem walaupun tidak menutup kemungkinan juga mengalami perubahan. Misalnya, pemakaian gendinggending seperti Gending Karawitan yang selalu dipergunakan oleh dalang tua, apa pun lakon yang dipergelarkan. Di lain pihak, dalang muda telah memilih gending yang sesuai dengan adegan yang dipergelarkan.

Fenomena yang menarik dalam jagad pedalangan bahwa para dalang tua pun sesungguhnya walaupun masih banyak menggunakan nuansa gending-gending iringan pakeliran dari kraton, tetapi banyak juga melakukan perubahan, khususnya dalam 
caking pakeliran yang ditandai dengan menghadirkan gending-gending baru dalam adegan tertentu, seperti pada adegan garagara. Faktor-faktor terjadinya perubahan adalah tren yang tengah terjadi di masyarakat, terutama penggemar dan penonton pergelaran wayang. Perubahan secara makro dalam jagad pedalangan sesungguhnya banyak dipengaruhi oleh taste serta trend yang terjadi di dalam masyarakat pedalangan sendiri ataupun masyarakat penonton wayang. Berbagai keinginan dari lingkungan penonton serta isu di kanan-kiri kehidupan sehari-hari, menjadi pemicu munculnya perubahan itu sendiri. Faktor-faktor terjadinya itu antara lain sebagai berikut.

1. Faktor politis adalah usaha-usaha sejak lama adanya maksud-maksud tertentu berkenaan dengan penyelenggaraan pergelaran cerita lakon wayang. Misalnya zaman raja-raja Jawa, khususnya Surakarta dan Yogyakarta masih berkuasa, pada waktu tertentu menyelenggarakan pertunjukan cerita lakon wayang yang disesuaikan dengan kepentingan raja. Dalam keadaan seperti ini pergelaran wayang diperuntukkan guna melegimitasi keberadaan raja yang bersangkutan. Misalnya, lahirlah lakon wayang Semar Boyong, Rama Nitik, Rama Nitis, Endang Werdiningsih, Parta Krama, Srikandhi Maguru Manah, Sembadra Larung, dan seterusnya. Selanjutnya, pada era pemerintahan Orde Baru yang ditandai dengan peristiwa up grading para dalang di kota Pekalongan 1967 (Kayam, 2001: 57), pertunjukan wayang banyak menyampaikan program-program pemerintah, yaitu berisi pesan-pesan pembangunan sehingga wayang dipergunakan sebagai alat propaganda oleh pemerintah. Ditandai dengan lakon Pendawa Tani, Mbangun Prabayeksa, Gawe Kali Srayu, dan sebagainya. Demikian halnya era reformasi, pertunjukan wayang dipergunakan sebagai alat komunikasi publik berupa nuansa tuntutantuntutan masyarakat tentang perubahan dan demokratisasi sehingga muncul lakon
Senar Gugat, Wisanggeni Gugat, Petruk Nagih Janji, dan sebagainya. Sementara itu, pemunculan gending-gending pun menjadi semarak walaupun masih banyak terkait dengan dolanan dalam adegan gara-gara, seperti munculnya gending Nusantara, Dirgahayu, P4, Keluarga Berencana, Bersih Desa, PKK, dan seterusnya.

2. Faktor pendidikan; kesadaran para dalang untuk meningkatkan kualitas pakelirannya, maka di samping menjadi abdi dalem kraton, mereka sekaligus mengikuti program pendidikan khusus yang diselenggarakan secara informal oleh pihak-pihak swasta yang peduli terhadap seni pedalangan. Misalnya, Habirandha, Sanggar Sekar Rinonce, Bale Budaya, dan sebagainya.

3. Faktor ekonomi, yang dimaksud adalah sisi kehidupan keseharian para dalang. Dalang bukan lagi sebagai sebuah hobi atau kesenangan, melainkan adalah pekerjaan. Tidak aneh bahwa para dalang profesional itu hanya mengandalkan kehidupannya sebagai dalang. Sebagian besar dalang tidak punya lahan garapan tanah pertanian sebagaimana kebanyakan masyarakat Jawa, apalagi sebagai pedagang dan pekerja harian atau buruh, hampir pasti tidak dapat dilakukannya. Oleh sebab itu, usaha peningkatan kualitas pakelirannya ke arah yang lebih baik dan kekinian merupakan usaha prioritas peningkatan kualitas pergelarannya.

\section{Struktur Naratif Warna Pekeliran dan Penggunaan Gending-gending Iringan Pakeliran}

Struktur naratif sesungguhnya adalah perjalanan sebuah cerita lakon wayang. Keberadaan struktur naratif begitu lekat dengan gending. Setiap penyajian pergelaran lakon wayang, gending-gending pakeliran memegang peranan yang sangat penting sehingga sering disebut juga struktur penyangga utama pergelaran wayang kulit purwa. Beberapa nama dalang yang 
dipergunakan sebagai data primer penelitian ini hampir pasti semuanya menggunakan gending-gending standar. Sebagaimana disampaikan oleh Mudjantistomo dan kawankawan (1977), dalam penyajian berbagai gending itu menyatu dengan struktur naratif cerita lakon wayang yang disajikan oleh maisng-masing dalang. Tidak menutup kemungkinan adanya pergeseran yang mengarah kepada gejala-gejala perbedaan yang dipandang juga sebuah pembaharuan. Untuk memudahkan pemahaman distribusi gendinggending tersebut, tentunya tidak dapat begitu saja dilepaskan dari unsur struktur naratifnya sehingga dengan sendirinya untuk memudahkan pembacaan dari masing-masing dalang, penyajian distribusi gendingnya dibuat dalam bentuk skema. Selanjutnya, skema struktur naratif dengan distribusi gendinggending iringan pakeliran akan dapat terbaca pada masing-masing dalang seperti berikut ini.

Estetika pedalangan secara tradisional telah dikenal istilah sanggit, yakni cara penyajian sebuah lakon dalam pertunjukan wayang. Sesungguhnya pengertian sanggit itu lebih mengarah pada pengetahuan teknis yang berkaitan dengan garap cerita lakon wayang. Oleh sebab itulah Soetarno (2007: 47) mengatakan bahwa cerita lakon wayang sesungguhnya merupakan manifestasi sanggit yang diterapkan dalam bangunan cerita lakon wayang. Sebuah sajian cerita lakon wayang menjadi bagus dan menarik yang didasari ide gagasan lakon yang bagus, kemudian diolah serta digarap dengan baik pula, maka hasilnya juga akan mampu menampilkan sajian sangat bagus. Selanjutnya dijelaskan bahwa ada lima konsep dasar estetika cerita lakon wayang yang menggunakan istilah-istilah tradisional bahasa Jawa, yaitu trep, tutug, mungguh, kempel, dan mulih. Trep berkaitan dengan durasi waktu antara cerita lakon wayang dan lama waktu pertunjukannya. Hal ini biasanya berorientasi pada jenis pertunjukan antara tradisi dan nontradisi, artinya pertunjukan semalam suntuk. Konsep tutug memberikan pengertian penyelesaian cerita lakon wayang. Artinya, suatu lakon dipergelarkan secara tuntas, tiada satu pun kisah ataupun tokoh wayang yang tercecer. Misalnya, tokoh wayang pada adegan pertama dari jejeran pertama tampil maka secara runtut pada akhir cerita pun terbaca. Demikian halnya lakon Gathutkaca Ratu, maka di akhir kisah pun penonton dapat mengetahui adegan tersebut tergambar dengan jelas. Konsep mungguh adalah mengacu pada orientasi cerita lakon yang menjurus pada hal-hal yang baik sehingga tidak ada unsur-unsur atau dibumbui sesuatu yang tidak pada tempatnya, seperti hal-hal yang keluar dari etika wayang. Contoh konkret adalah penggunaan kosakata yang menjurus ke arah negatif, seperti jorok, porno, kasar, dan sebagainya. Konsep kempel adalah kebulatan cerita lakon dengan berbagai unsur dalam sebuah pertunjukan secara lengkap. Konsep mulih, artinya bahwa semua kisah cerita lakon dapat memperoleh penyelesaian berbagai permasalahan yang ada sejak awal sampai dengan akhir cerita lakon secara runtut dan tuntas. Paparan konsep pemikiran tradisional itu sesungguhnya secara implisit telah terwadahi di dalam konsep estetika Barat yang telah disampaikan oleh The Liang Gie (2004), serta struktur perjalanan cerita lakon sebagaimana gaya Aristotalian (Satoto, 1985).

Sanggit wayang dapat diibaratkan sebuah pola, motif, atau variasinya yang sangat bergantung pada sanggit masing-masing dalang. Cerita lakon wayang yang sederhana dapat menjadi menarik dan satisfikatif atau rumit di tangan seorang dalang yang mumpuni, yang piawai mengolah permasalahan-permasalahan dan konflik sebuah cerita lakon wayang. Sebab, lakon itu secara mendasar adalah timbunan konflik antartokoh wayang. Sanggit juga diartikan sebagai cara interpretasi dalang terhadap sebuah karya cerita lakon wayang sebelumnya sehingga sangatlah dimungkinkan terjadi perubahan walaupun hanya sedikit (Nugroho, 2012: 99). Cerita lakon wayang sebagai suatu bentuk tradisi sastra lisan dalam tanda petik, memiliki kemungkinan terjadi- 
nya perubahan dan pergeseran. Hal itulah kenyataan berbagai cerita lakon wayang yang tersebar di kawasan Yogyakarta mengalami persebaran, sesuai lokalitas domisili kewilayahan dalang yang bersangkutan. Ada dalang lor negara, kidul negara, kulon negara, dan wetan negara yang semua bersumber serta berkiblat dari tradisi kraton Yogyakarta (Hadiprayitno, 2019:20-25).

Berdasarkan uraian terdahulu diketahui bahwa gending-gending iringan lakuan wayang terdiri atas bentuk dan isi. Bentuk menyangkut tentang fisik gending-gending iringan wayang, misalnya bentuk lancaran, ladrang, ketawang, gending, ayak-ayakan, playon, sampak, dan sebagainya, sedangkan isi adalah jenis-jenis sistem garap gending tertentu yang menyangkut persoalan teknis, misalnya gending-gending iringan wayang gaya Yogyakarta yang telah dibakukan dalam buku pengajaran Habirandha Kraton Yogyakarta yang ditulis oleh Mudjanattistomo (1977). Secara baku, iringan wayang gaya Yogyakarta yang pasti tidak dapat dipisahkan dengan penyajian lakon adalah gending Karawitan untuk jejeran pertama yang diawali dengan bentuk gending ayak-ayak, dan berakhir dengan bentuk gending Ladrang Karawitan, yang semua berada dalam Laras Slendro Pathet Nem. Tidak tergantung cerita lakon wayang yang dibawakan oleh dalang, gending tersebut selalu dipergunakan mengiringi jejeran pertama. Secara komprehensif berdasarkan struktur penyajian lakon, diberikan contoh praktik pakeliran, dimulai dari urutan pengadegan dalam lakon Aji Narantaka (Mudjanattistomo, dkk., 1977: 214-253).

Penyusunan alur atau plot dalam cerita lakon wayang tidak dapat dipisahkan dengan pengertian lakon itu sendiri. Suatu lakon mengandung tiga bagian utama yang dalam setiap pembagian itu mempunyai rentang titi nada suara tertentu dan penilaian atas titi nada suara yang tertentu itu selalu dipertahankan. Di samping itu, di dalam bagian tersebut terdapat struktur internal yang telah ditentukan sebelumnya. Bagian- bagian inilah yang lazim disebut dengan pathet. Setiap pathet mencakup kombinasikombinasi suasana, seperti jejer, adegan, adegan perang, dan sebagainya.

Struktur lakon wayang dibangun di atas plot yang terdiri dari urutan-urutan yang berupa kejadian-kejadian atau peristiwa yang terjelma ke dalam episode-episode yang bersiklus (Becker, 1979: 218-223). Suatu plot lakon wayang membicarakan gambaran sebuah tindakan, suatu cara, dan peristiwa. Lakon wayang disusun berdasarkan tiga bagian utama yang masing-masing bagian dibatasi oleh rentang titi nada suara gamelan. Pada setiap bagian itu terdapat struktur internal yang telah ditentukan. Bagian-bagian itu disebut pathet yang meliputi pathet Nem, pathet Sanga, dan pathet Manyura.

Selanjutnya, dipaparkan struktur pementasan lakon wayang kulit purwa berdasarkan tradisi pewayangan Yogyakarta (Mudjanattistomo, dkk., 1977: 162-167), disesuaikan dengan rentang titi nada dasar bunyi gamelan yang disebut pathet, yang meliputi tiga bagian wilayah nada sebagai berikut:

\section{Pathet Nem}

a. Jejer pertama. Pada jejer ini biasanya kisah terjadi di sebuah istana, raja bertakhta di hadapan para punggawa. Pada bagian ini suatu peristiwa mulai dibahas dan disusun rencana untuk menentukan jalan keluarnya. Benih plot mulai dipaparkan (Wiryamartana, 1990: 349), kemungkinan benih plot itu justru telah muncul pada peristiwa sebelumnya. Penggunaan gending iringan pada jejer pertama meliputi, 1) Ayak-ayak pathet Nem yang diikuti dengan 2) Gending Karawitan Slendro Pathet Nem bersamaan dengan dalang mendeskripsikan jejeran yang disebut janturan. Istilah janturan ini hanya digunakan untuk jejer pertama. Setelah selesai janturan gending beralih ke 3) Gending Ladrang Karawitan, kemudian suwuk; dalang membawakan sulukan lalu dialog antartokoh wayang. Setelah jejer pertama berakhir dilanjutkan dengan 
adegan yang merupakan rangkaian dari jejer pertama sebagai berikut.

1) Adegan Kedhatonan; adegan ini berisi pertemuan antara raja dan permaisurinya, dilanjutkan dengan limbukan, yaitu dialog antara tokoh limbuk dan cangik. Mereka berbincang-bincang berbagai hal yang berkaitan dengan masalah-masalah kehidupan seharihari, kadang-kadang dengan lawakan serta tarian dan nyanyian. Gending yang digunakan kebanyakan adalah ayak-ayak, Karawitan, dan gendinggending ladrangan dan dolanan.

2) Adegan Paseban Jawi; bagian ini apabila menggunakan gending iringan maka harus disertai dengan carita, setelah dialog dilanjutkan budhalan dan perangampyak. Sering terjadi dalam pementasan ditemukan adegan perang yang lain yang disebut perang kembang. Gending yang dipakai dalam adegan ini adalah bentuk gending lancaran.

b. Jejer kedua. Pelaksanaan jejer ini setelah semua rangkaian pada jejer pertama selesai. Adapun adegan perang yang terdapat dalam jejer disebut perang simpangan. Gending yang dipergunakan pada jejer kedua menyesuaikan dengan tokoh yang ditampilkan, misalnya jika tokoh wayangnya alusan maka dipakailah gending bentuk ladrang atau gending sacandra, seperti gending Bondhet. Manakala tokohnya adalah gagahan atau raksasa maka dipakai gending Ladrang Sarayuda, Wirangrong, Diradameta, Jati Kumara, dan seterusnya.

c. Jejer ketiga. Setelah semua rangkaian jejer sebelumnya selesai, menyusul jejer ketiga. Dalam bagian ini, jenis gending iringan yang dipergunakan merupakan peralihan dari Pathet Nem ke Pathet Sanga sehingga setelah bunyi gending gamelan suwuk, sulukan yang dinyanyikan dalang pun harus beralih ke Pathet Sanga, yaitu suluk Lagon Sanga Wetah. Pada pelaksanaan pemen- tasan, kedudukan jejer ketiga sering digantikan dengan bentuk gladhagan, yaitu sebuah adegan yang tidak mempergunakan gending, tetapi menggunakan iringan playon, dan dengan sendirinya kedudukan carita digantikan kandha. Apabila dalam rangkaian adegan ini dijumpai peristiwa perang, maka perang itu disebut perang gagal.

\section{Pathet Sanga}

a. Adegan Gara-gara. Adegan ini tidak termasuk dalam jejeran, adapun pelaksanaannya diperhitungkan pada waktu tengah malam. Bagian ini merupakan kesempatan bagi dalang untuk menampilkan lawakan melalui tokoh-tokoh Punakawan, yaitu Semar, Gareng, Petruk, dan Bagong. Adegan gara-gara merupakan media yang tepat untuk menyampaikan pesan-pesan dari penanggapnya. Pada zaman rezim Orde Baru, dalang banyak menyampaikan program pemerintah lewat adegan gara-gara.

b. Jejer keempat. Tempat terjadinya jejer ini biasanya di pertapaan, hutan, atau istana, tergantung pada alur cerita lakon yang dipentaskan. Adegan perang pada rangkaian jejer ini disebut perang begal, berupa perang antara kesatria melawan raksasa atau binatang jelmaan dewa, tergantung lakon yang dipentaskan.

c. Jejer kelima. Jejeran ini sering disebut jejer uluk-uluk, artinya sebagai pemberi isyarat bahwa lakon wayang telah sampai pada inti cerita. Apabila waktu pementasan sangat mendesak, jejeran ini digantikan dengan bentuk gladakan, begitu juga jejer berikutnya. Pada jejer ini terdapat transisi dari Pathet Sanga ke Pathet Manyura. Adegan perang yang terdapat pada rangkaian ini disebut perang tanggung. Sulukan yang dibawakan dalang telah menggunakan suluk Pathet Manyura wetah.

\section{Pathet Manyura}

a. Jejer keenam, isi cerita mengarah ke penyelesaian lakon. Adapun adegan perang terdapat pada rangkaian jejer 
keenam disebut perang tandang.

b. Jejer ketujuh, disebut jejer Pathet Galong. Sulukan yang dilagukan oleh dalang adalah suluk galong wetah. Sulukan ini sekaligus sebagai pemberi isyarat kepada penabuh gamelan agar membunyikan gending yang berakhir dengan gong nada tiga tanda perpindahan dari Pathet Manyura ke Pathet Galong. Adegan perang pada jejer ketujuh disebut perang brubuh. Pementasan lakon diakhiri dengan tarian golek kayu, kemudian tancap kayon, yaitu dalang menancapkan kayon atau gunungan di tengah, di antara jajaran tokoh wayang sebagai tanda pementasan lakon telah selesai.

\section{Penutup}

Setelah diuraikan berbagai hal yang terkait dengan pokok penulisan dan tujuannya, maka dapat ditarik beberapa kesimpulan sebagai berikut.

1. Setiap pergelaran wayang kulit purwa gagrag ngayogyakarta atau gaya pedalangan, keberadaan musik gending gamelan memiliki peranan penting sebagai iringan lakuan gerak-gerak wayang. Lakuan gerak wayang menentukan jenis dan macam wayang yang ditampilkan oleh dalang.

2. Relasitas dalam pergelaran wayang ditentukan oleh suasana adegan, suasana batin tokoh wayang, seperti marah, senang, agung, sedih, dan sebagainya. Gending yang mengiringi pergelaran wayang secara umum meliputi bentuk gending ageng, ladrang, ketawang, lancaran, playon, sampak, dan lain-lain, sesuai keinginan yang dibangun dalam sajian lakon, suasana, dan karakter wayang.

3. Antara gerak lakuan wayang dan gending iringan ditentukan sedemikian rupa berdasarkan kebutuhan dalam pergelaran sehingga membentuk satu jalinan harmonisasi. Hal tersebut penting diperhatikan agar dominasi gerak wayang dengan iringan terjaga dengan baik.
4. Hasil pembahasan menujukkan bahwa dalam sajian pergelaran wayang kulit gaya pedalangan secara umum adalah terpenuhinya kesatuan bentuk, kompleksitas, dan kemapanan penataan gerak dan iringan sehingga mampu membedakan dengan karya-karya seni pewayangan lainnya.

\section{Kepustakaan}

Becker, A. L. 1979. Tex-Building, Epistemology, and Aesthetics in Javanese Shadow Theatre. In A. L. Becker, A. A. Yengoyan, \& Et.al. (Eds.), The Imagination and Reality: Essays on Southeast Asia Coherence System. Ablex Publication.

Dewey, J. 1934. Art as Experience. Penguin Group.

Gie, T. L. 2004. Filsafat Keindahan. Pusat Belajar Ilmu Berguna (PUBIB).

Gustami, S. 2000. Studi Komparatif Seni YogyaSolo. Yayasan Untuk Indonesia.

Hadiprayitno, K. 2017. Estetika Pedalangan Ruwatan Murwakala Kajian Estetika dan Etika Budaya Jawa. BP ISI Yogyakarta.

Hadiprayitno, K. 2019. Literatur Pedalangan: Balungan Lakon Wayang Gagrag Ngayogyakarta Serial HarjunasasraRamayana Sasana Hinggil Dwi Abad 2016-2017. Penerbit Dinas Kebudayaan Provinsi Daerah.

Haryanto, S. 1988. Pratiwimba Adhiluhung Sejarah dan Perkembangan Wayang. Djambatan.

Kayam, U. 2001. Kelir Tanpa Batas. Gama Media.

Mudjanattistomo, dkk. 1977. Pedhalangan Ngayogyakarta Jilid I. Yayasan Habirandha. Nojowirongko. 1960. Serat Tuntunan Pedhalangan Tjaking Pakeliran Lampahan Irawan Rabi Djilid I. Tjabang Bagian Bahasa.

Nugroho, S. 2012. Sanggit dan Garap Lakon Banjaran Pertunjukan Wayang Kulit Purwa Gaya Surakarta. Sekolah Pascasarjana UGM.

Palmer, R. E. 2005. Hermeneutika Teori Baru 
Mengenai Interpretasi. Pustaka Pelajar Offset.

Satoto, S. 1985. Wayang Kulit Purwa Makna dan Struktur Dramatiknya. Proyek Penelitian dan Pengkajian Kebudayaan Nusantara (Javanologi) Direktorat Jenderal Kebudayaan Departemen Pendidikan dan Kebudayaan.

Soedarsono, R. M. 1990. Wayang Wong: The State Ritual Dance Drama in the Court of Yogyakarta. Gadjah Mada University Press.

Soetarno, Sunardi, dan Sudarsono. 2007.
Estetika Pedalangan. ISI Surakarta dan CV Adji Surakarta.

Solichin, dkk. 2012. Pendidikan Budi Pekerti dalam Pertunjukan Wayang. Senawangi. Sumarsam. 2003. Gamelan: Interaksi dan Perkembangan Musikal di Jawa. Pustaka Pelajar.

Sumukti, T. 2005. Semar, Dunia Batin Orang Jawa (I. Gusmian (ed.)). Galang Press.

Wiryamartana, I. K. 1990. Arjunawiwaha Transformasi Teks Jawa Kuna Lewat Tanggapan dan Penciptaan di Lingkungan Sastra Jawa. Duta Wacana University Press. 